\title{
Muscle precursor cells in the developing limbs of two isopods (Crustacea, Peracarida): an immunohistochemical study using a novel monoclonal antibody against myosin heavy chain
}

\author{
S. Kreissl • A. Uber · S. Harzsch
}

Received: 14 December 2007 / Accepted: 20 March 2008/Published online: 29 April 2008

(C) The Author(s) 2008

\begin{abstract}
In the hot debate on arthropod relationships, Crustaceans and the morphology of their appendages play a pivotal role. To gain new insights into how arthropod appendages evolved, developmental biologists recently have begun to examine the expression and function of Drosophila appendage genes in Crustaceans. However, cellular aspects of Crustacean limb development such as myogenesis are poorly understood in Crustaceans so that the interpretative context in which to analyse gene functions is still fragmentary. The goal of the present project was to analyse muscle development in Crustacean appendages, and to that end, monoclonal antibodies against arthropod muscle proteins were generated. One of these antibodies recognises certain isoforms of myosin heavy chain and strongly binds to muscle precursor cells in malacostracan Crustacea. We used this antibody to study myogenesis in two isopods, Porcellio scaber and Idotea balthica (Crustacea, Malacostraca, Peracarida), by immunohistochemistry. In these animals, muscles in the limbs originate from single muscle precursor cells, which subsequently grow to form multinucleated muscle precursors. The pattern of primordial muscles in the
\end{abstract}

Communicated by S. Roth

Electronic supplementary material The online version of this article (doi:10.1007/s00427-008-0216-1) contains supplementary material, which is available to authorized users.

S. Kreissl · A. Uber

Universität Konstanz, Fakultät für Biologie, Neurobiologie,

78434 Konstanz, Germany

S. Harzsch $(\square)$

Department of Evolutionary Neuroethology,

Max Planck Institute for Chemical Ecology,

Beutenberg Campus, Hans-Knöll-Str. 8,

07745 Jena, Germany

e-mail: sharzsch@ice.mpg.de thoracic limbs was mapped, and results compared to muscle development in other Crustaceans and in insects.

Keywords Muscle precursor - Isopoda - Crustacea . Appendage $\cdot$ Evolution

\section{Introduction}

Amongst all arthropods, Crustaceans display the greatest variety of different limb types, and the morphology of their appendages has played an outstanding role in the raging debate on arthropod phylogeny (reviews, e.g. Williams and Nagy 1996; Boxshall 1997; Kukalova-Peck 1997; Browne and Patel 2000; Bitsch 2001; Klass and Kristensen 2001; Schram and Koenemann 2001; Williams and Nagy 2001; Wolf and Harzsch 2002; Waloszek 2003; Williams 2004). The recent move towards integrating the fields of evolutionary and developmental biology (e.g. Averof and Akam 1995; Gilbert et al. 1996; Akam 1998a; Hughes and Kaufman 2000; Harzsch and Hafner 2006; Harzsch 2007) has fostered a surge of studies on Crustacean limb development which examined the expression and function of genes such as Distal-less (Panganiban et al. 1995; Popadic et al. 1996, 1998; Scholtz et al. 1998; Williams 1998, 2008; Williams et al. 2002), Ultrabithorax and AbdominalA (Averof and Akam 1995; Averof and Patel 1997), Extradenticle (Gonzáles-Crespo and Morata 1996; Abzhanov and Kaufmann 2000), Pdm and Apterous (Averof and Cohen 1997), Sex combs reduced (Abzhanov and Kaufman 1999), and Wingless (Nulsen and Nagy 1999) in various Crustacean taxa with uniramous, biramous or phyllopodous branched limbs. Interestingly, some of these studies failed to establish homologies between the function of these genes during development of the complex 
Crustacean limbs as compared to the uniramous limbs of Insecta (Williams and Nagy 1995, 1996; Averof and Patel 1997; Williams et al. 2002; Williams 2004) but instead established new hypotheses on the evolution of hox gene function (Averof et al. 1996; Akam 1998b). The emerging picture is that limb patterning genes seem to act differently in the insect with uniramous limbs and those Crustaceans with phyllopodous limbs, and therefore, a greater knowledge of the cellular foundations of limb development in Crustaceans is essential to establish an interpretative context in which to analyse gene functions. However, few papers have recently dealt with cellular aspects of Crustacean limb development other than gene expression (e.g. Williams and Müller 1996; Ungerer and Wolff 2005; Kiernan and Herzler 2006).

Concerning the neuromuscular innervation, there is evidence for close similarities between Hexapoda and malacostracan Crustacea. In these animals, each thoracic walking leg is supplied by a set of exactly three inhibitory motoneurons in addition to its excitatory innervation. Wiens and Wolf (1993) have shown that the inhibitory limb innervation in a crayfish displays striking similarities to that in Hexapoda down to the level of single identified cells. The sets of inhibitors in these taxa share a number of morphological, physiological and biochemical characteristics which suggest homology, as discussed in greater detail by Harzsch (2007). Furthermore, the innervation pattern of particular excitatory motoneurons in crayfish and locusts provides new insights into the alignment of malacostracan Crustacean and insect trunk limbs (Wiens and Wolf 1993). These authors suggest a homology of the extensor muscles located within the second podomeres of insect and malacostracan limbs (merus and femur) and therefore support a close correspondence of limb segmentation in Malacostraca and Hexapoda (discussed in more detail by Wolf and Harzsch 2002; Harzsch 2007). Because information on inhibitory and excitatory leg motoneurons so far is only available for malacostracan Crustacea but not for the other Crustacean taxa, these comparisons so far are only of a limited phylogenetic value. However, these studies signify that comparative analyses of the neuromuscular system have a significant potential to contribute new insights into the evolution of arthropod appendages.

The cellular basis of embryonic muscle formation in Crustaceans is poorly understood, although ontogenetic aspects of the neuromuscular system (reviewed in Govind 1982; Govind and Walrond 1989; Govind 1995) and moultinduced muscle atrophy and regeneration (reviewed in El Haj 1999; Mellon 1999; Mykles 1999; Govind 2002) have been studied in some detail. The goal of the present project was to analyse muscle development in Crustacean appendages, and therefore, we generated monoclonal antibodies against arthropod muscle proteins. One of these antibodies,
016C6, strongly labelled muscle precursor cells in malacostracan Crustacea and on Western blots was shown to recognise several isoforms of myosin heavy chain in rabbit, grasshopper and Crustaceans. We used this antibody to study muscle formation in two isopods, the terrestrial Porcellio scaber Latreille, 1804 (Crustacea, Malacostraca, Peracarida, Isopoda, Oniscidea; Fig. 1) and the marine Idotea balthica Pallas 1772 (Valvifera) by immunohistochemistry. In these animals with uniramous walking legs (Fig. 1), muscles of the body wall and the limbs were shown to originate from single muscle precursor cells, which subsequently grow to form multinucleated muscle precursors. The pattern of primordial muscles in the thoracic limbs was mapped, and results compared to muscle development in insects (reviewed in Campos-Ortega and Hartenstein 1997; Abmayr and Keller 1998; Baylies et al. 1998; Paululat et al. 1999a, b; Roy and VijayRaghavan 1999).

\section{Materials and methods}

Animals

I. balthica Pallas 1772 (Crustacea, Malacostraca, Peracarida, Isopoda, Valvifera; Fig. 1A) were obtained from the Biologische Anstalt Helgoland and kept in artificial seawater at $16^{\circ} \mathrm{C}$ at the University of Konstanz (compare Kreissl et al. 1999). Eriphia spinifrons (Crustacea, Mala-
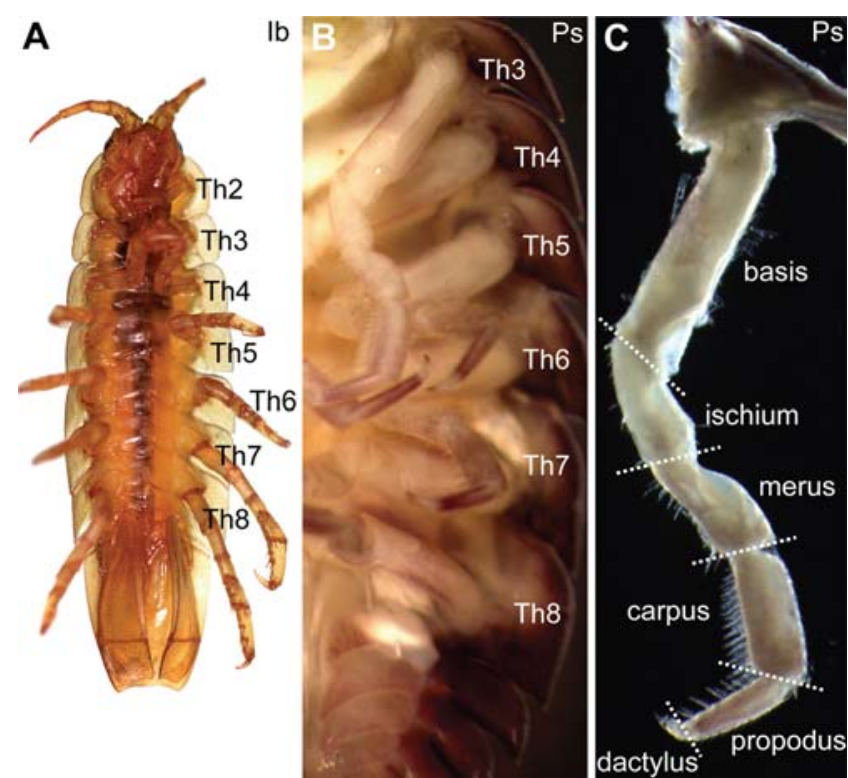

Fig. 1 The walking limbs of adult isopods: A ventral view of an adult male of $I$. balthica. The labels Th2 to Th8 identify the thoracomeres. B Adult specimen of $P$. scaber, ventral view (medial is towards the right) of thoracomeres three to eight (Th3-Th8) with the walking limbs attached. C Higher magnification of the walking limb from thoracomere three (P. scaber) to show podomeres (medial is towards the left). Abbreviations: letters in the upper right corners identify the species 
costraca, Decapoda, Brachyura) and Idotea emarginata (Crustacea, Malacostraca, Peracarida, Isopoda, Valvifera) were obtained from the Stazione Zoologica Anton Dhorn in Naples. P. scaber Latreille, 1804 (Crustacea, Malacostraca, Peracarida, Isopoda, Oniscidea; Fig. 1B, C) were collected on the campus surrounding the University of Konstanz. For the experiments, embryos were gently removed from the brood pouches of ovigerous females.

Generation and characterisation of the antibody 016C6

A crude myosin extract (d'Albis et al. 1979) of meso- and metathoracic locust muscles was used as the antigen to immunise mice. Two mice (female Balb/c, 6 weeks of age) received $0.1 \mathrm{ml}$ of myosin extract emulsified in a $1: 1$ relation in RIBI adjuvant system, (MPL+TDM emulsion, R-700; RIBI Immunochem Research Inc.) at each of two subcutaneous sites on day 0 and day 28 and three final immunisations intraperitoneally with $50 \mu \mathrm{l}$ myosin extract after 15 weeks. The mice sera were tested for antibodies on enzyme-linked immunosorbent assay (ELISA) coated with crude myosin extract. Both mice showed strong immune responses. Three days later, splenectomy was performed, and the splenocytes were fused with a mouse myeloma cell line (P3X63Ag8.653, ATCC CRL-1580) by PEG-1500. The successfully fused hybridomas were selected in Roswell Park Memorial Institute (RPMI)-1640 medium supplemented with HAT (10 mM hypoxanthine, $40 \mu \mathrm{M}$ aminopterin, $1.6 \mathrm{mM}$ thymidine; GIBCO BRL, Carlsbad, CA, USA), $10 \%$ foetal bovine serum, $24 \mu \mathrm{M} \beta$-mercaptoethanol and Nutridoma-CS (Roche, Indianapolis, IN, USA). The culture supernatants were collected and screened by ELISA. The reactions were confirmed with Western blot analysis and immunostaining on cryosections of native and paraformaldehyde fixed locust muscles using secondary antibody conjugated to $\mathrm{Cy} 3$ or $\mathrm{Cy} 2$ (Jackson Labs). Positive clones were selected by at least three sets of the limiting dilution technique. The antibodies generated against locust muscle proteins were also screened for their binding affinity to muscle tissue of malacostracan Crustaceans and of rabbits. For the identification of the antigen in Western blots, the crude myosin extracts (d'Albis et al. 1979) of locust muscles, of abdominal muscles of the two Crustacean species $E$. spinifrons and I. emarginata and of adult White New Zealand rabbit muscles (psoas, soleus and diaphragm) were separated by sodium dodecyl sulfate-polyacrylamide gel electrophoresis (SDS-PAGE) on 7.5\% linear gels according to standard techniques. The proteins were transferred to cellulose nitrate membranes (Protran, Schleicher \& Schuell $\mathrm{GmbH}$, Dassel, Germany), and selective binding of monoclonal $\operatorname{IgG} 1 \kappa 016 \mathrm{C} 6$ to proteins was detected with the $\mathrm{IgG}$ ABC-ELITE-POD kit (Vector Labs) using ECL (Pierce) as a substrate. Molecular weight markers were biotinylated, allowing direct detection by the $\mathrm{ABC}$ reagent in the Western blots.

Whole mount immunohistochemistry

Embryos were fixed for $4 \mathrm{~h}$ in $4 \%$ paraformaldehyde in $0.1 \mathrm{M}$ phosphate buffer $(\mathrm{pH} 7.4)$ at room temperature. Whole mounts of the embryos were incubated in $1 \mathrm{mg} / \mathrm{ml}$ collagenase/dispase (Sigma) for $20 \mathrm{~min}$ at room temperature or pretreated with short ultrasonic pulses to increase penetration of the antibodies then washed in several changes of $0.1 \mathrm{M}$ phosphate-buffered saline (PBS) for $4 \mathrm{~h}$ and afterwards pre-incubated in PBS containing $1 \%$ normal goat serum and $0.3 \%$ Triton X-100 (PBS-TX) for $2 \mathrm{~h}$ at room temperature. Specimens were then incubated overnight at $4^{\circ} \mathrm{C}$ in supernatants of the monoclonal antibody 016C6 diluted 1:10 in PBS-TX. The omission of the primary antibody resulted in a complete absence of specific labelling. The embryos were then incubated in a biotinylated secondary antibody for $3 \mathrm{~h}$ (Jackson) and subsequently for another $3 \mathrm{~h}$ in peroxidase-conjugated streptavidin (Dianova). After washing for $4 \mathrm{~h}$ in PBS, the tissues were reacted with $0.013 \%$ diaminobenzidine and a reagent containing hydrogen peroxide, cobalt chloride and nickel chloride (Amersham, RPN 20) for 7-9 min to reveal the peroxidase label. Finally, whole-mount preparations were dehydrated and mounted in Eukitt (Riedel-de Haen). Preparations were observed with a Zeiss Axioskop and labelled structures drawn using a camera-lucida apparatus. The slides were also photographed on $35-\mathrm{mm}$ colour slide film, the images transferred onto Kodak Photo $\mathrm{CD}$ and processed in Picture Publisher. Alternatively, specimens were photographed with the Polaroid DMC10 digital camera.

\section{HOECHST stain}

To reveal the morphology of the early embryos, specimens were dissected out of the chorion and the yolk was removed. Specimens were then fixed in $4 \%$ paraformaldehyde in $0.1 \mathrm{M}$ phosphate buffer (1 h, room temperature) and stained with the nuclear dye bisbenzimide $(0.1 \%$, 15 min at room temperature; Hoechst $\mathrm{H}$ 33258), washed in buffer overnight and mounted in Flouromount (Sigma). Specimens were viewed with a fluorescent microscope (Axioskop) and documented as described above.

\section{Results}

Characterisation of monoclonal antibody 016C6

Screening the supernatants of a number of monoclonal hybridoma cell lines producing antibodies against locust 
muscle proteins for their binding affinity to muscle tissue of other species revealed that monoclonal antibody (MAB) 016C6 shows a particularly strong affinity for muscle proteins of malacostracan Crustaceans. For the identification of the 016C6 antigen, muscle proteins of Locusta migratoria, I. emarginata, E. spinifrons and of adult White New Zealand rabbits were separated by SDS-PAGE and analysed in Western blots. Polyacrylamide gel analysis of proteins of the muscle homogenates shows prominent bands with apparent molecular weights of 180 to $200 \mathrm{kDA}$, indicating the presence of myosin heavy chains in all tissues examined (Fig. 2A). In the four tested species, MAB 016C6 binds to muscle proteins with an apparent molecular weight of $180 \mathrm{kDA}$ (Fig. 2B).

In mammals, myosin heavy chains (MHC) exist as isoforms of polypeptides with a molecular mass of about 180-200 kDa. The homogenate of the rabbit psoas (fast twitch muscle) contains predominantly the MHC-IId isoform. The homogenate of the diaphragm contains MHC I, MHC IIa and MHC IId, the slow twitch and two fast twitch isoforms, respectively. The rabbit soleus (slow twitch muscle) contains predominantly myosin heavy chain MHC-I (Aigner et al. 1993). MAB 016C6 exhibits a considerably higher affinity to MHCs of the three arthropod species and to the slow MHC-I isorm of rabbit muscles as compared to the fast rabbit MHCs (Fig. 2). We used MAB $016 \mathrm{C} 6$ as a general marker for differentiating muscle cells already containing myosin heavy chains in the present study.
Development of the embryos

The embryonic development of two species of the genus Idotea has been described by Strömberg (1965), and the development of $P$. scaber was recently reviewed by Whitington et al. (1993) and Abzhanov and Kaufman (1999; see also Brena et al. 2005). Hejnol et al. (2006) explored germ band formation in this organism. For $P$. scaber, Whitington et al. (1993) established a percentage staging system based on developmental time. Under the rearing conditions described above, I. balthica embryos hatched after 27 days. However, a period of rapid organogenesis occurs during the last 6 or 7 days of embryogenesis (Fig. 3) so that a direct comparison of the ontogeny of I. balthica and P. scaber based on a percentage scale was not possible. Therefore, we subdivided the embryonic period that we studied into five distinct stages, which are comparable between the two species:

Stage 1 (I. balthica E70\%, P. scaber E40\%; the percentage values indicate embryonic development in a percentage staging system based on developmental time): The germ band is not completely elongated, and mitotic cells in the posterior growth zone are still visible; in the more anterior thoracomeres, distinct limb anlagen can be distinguished.

Stage 2 (I. balthica E80\%, P. scaber E60\%): All segments are formed, the embryo is not closed dorsally,
A

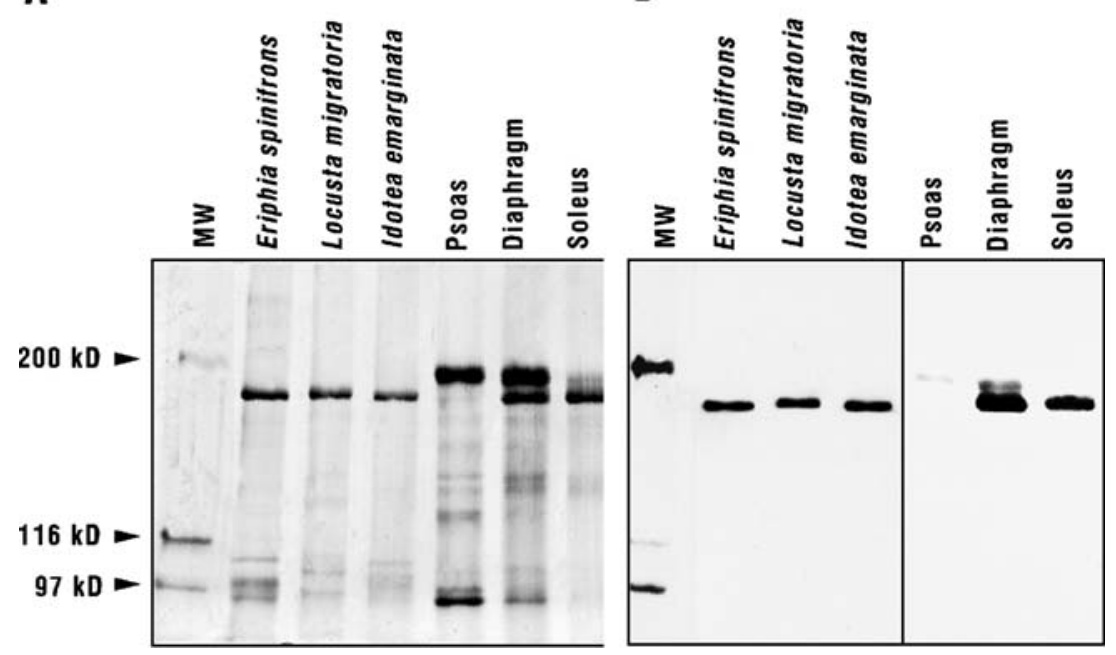

Fig. 2 Characterization of monoclonal antibody 016C6: 016C6 specifically binds to myosin heavy chains, which co-migrates with a slow myosin heavy chain isoform of rabbit muscles. A Separation of muscle proteins by SDS-PAGE. Numbers at the left indicate molecular weight markers $(M W)$, lanes 2-4 were loaded with muscle homogenates of the two malacostracan species E. spinifrons (Decapoda, Brachyura) and I. emarginata (Peracarida, Isopoda) and the hexapod
L. migratoria. Lanes 5-7 were loaded with homogenates of the fast type psoas muscle, the mixed type diaphragm and the slow type soleus muscle of rabbits. Myosin heavy chains are prominent at MW of 180 to $200 \mathrm{kDA}$. B Identification of the $016 \mathrm{C} 6$ antigen by Western blot analysis reveals myosin heavy chains in arthropod muscles which comigrate with a $180 \mathrm{kDA}$ myosin heavy chain isoform of rabbit slow and mixed muscles 
Fig. 3 Embryonic staging system: A-C embryos of I. balthica at $\mathbf{A} 70 \%$ of embryonic development (E70\%; stage 1), B E85\% (stage 3) and C E95\% (stage 4-5). D Embryo of $P$. scaber at $\mathrm{E} 60 \%$ (stage 2). E, F embryos of P. scaber at $\mathbf{E ~ E 4 0 \% ~}$ (stage 1) and F E60\% (stage 2), HOECHST nuclear stain, ventral views. At stage 1, the germ band is not completely elongated, and limb anlagen are visible in the anterior thoracic segments. At stage 2, all segments are formed, and the thoracic limb anlagen are subdivided into distinct podomeres. Abbreviations: letters in the upper right corners identify the species and larval stages; $A 1-2$ antenna 1 and 2, GZ posterior growth zone, $L B$ labrum, $M D$ mandible, $M X 1-2$ maxilla 1 and 2, T18 thoracomeres 1 to $8, P 1-5$ pereomeres 1 to 5 , the last pleomeres denoted. Scale bars A-F, $100 \mu \mathrm{m}$
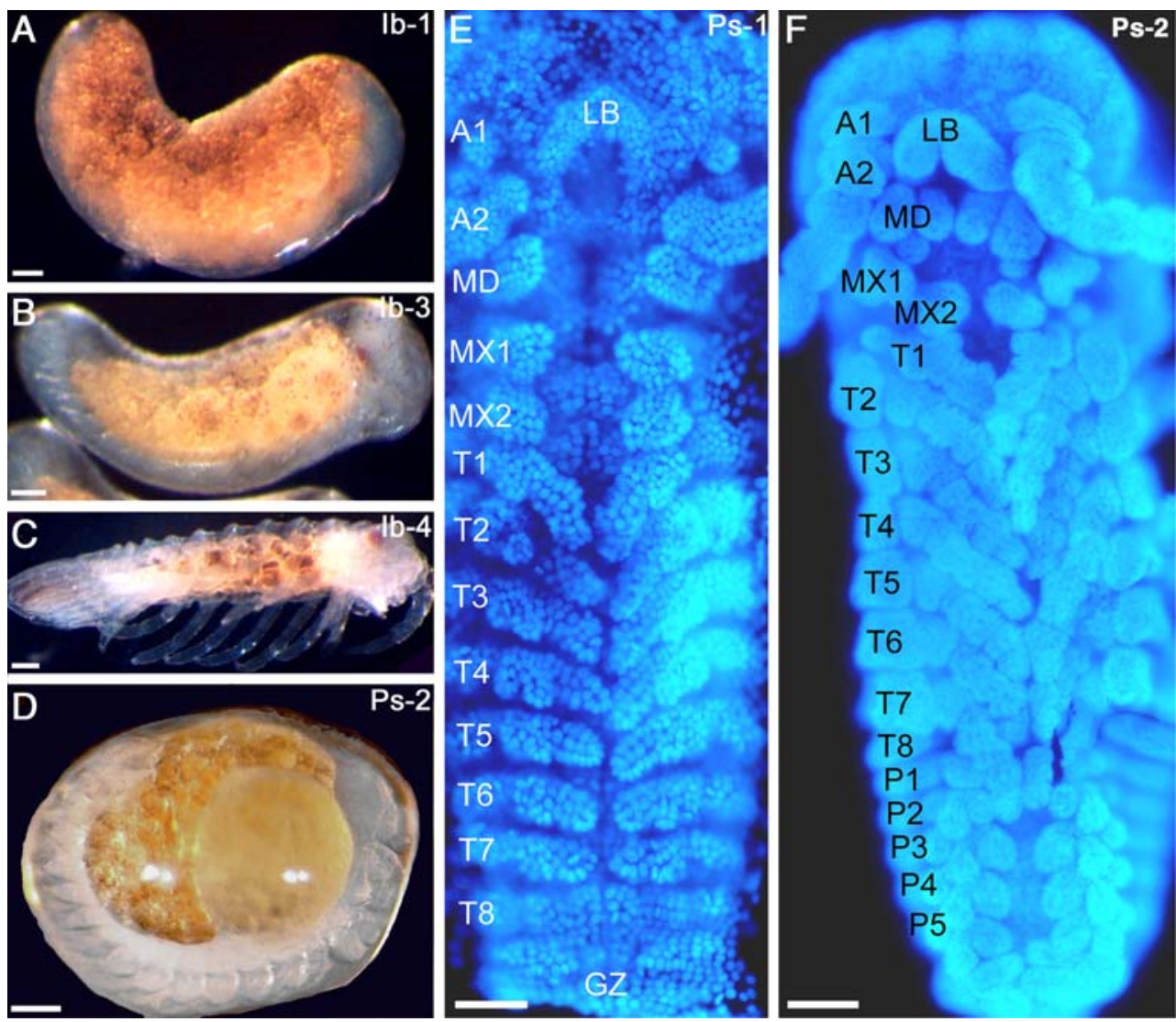

and the limb anlagen are subdivided into distinct podomeres.

Stage 3 (I. balthica E85\%, P. scaber E80\%): Red pigments is visible throughout the entire embryo, the first ommatidia can be distinguished, and single muscle precursor cells can be labelled immunohistochemically in the limb anlagen.

Stage 4 (I. balthica E90\%, P. scaber E90\%): The growing tergites have dorsally enclosed the yolk.

Stage 5 (I. balthica E100\%, P. scaber E100\%): hatching

Development of the thoracic limbs

A stage 1, embryo of $P$. scaber labelled with the HOECHST stain is shown in Fig. 3E. Proliferating cells in the posterior growth zone have just generated the first pleomere, and limb buds are beginning to form in the thoracic segments at that stage. The thoracic limb anlagen subsequently enlarge, and bilobed anlagen of the pleopods appear (Fig. 4A, late stage 1). In stage 2 embryos, the developing thoracopods begin to subdivide into distinct subunits, the podomeres (Fig. 3E, F4B), and the adult subdivision of the thoracopods into seven subunits is established: coxa, basis and the five endopodal podomeres ischium, merus, carpus, propodus, dactylus (Fig. 4B). At this stage, the limb anlagen are well developed in all pleonic and thoracic segments except thoracomere 8 . The eighth thoracopods are not present in embryos (Fig. 4A,B) but develop postembryonically (Fig. 1; see Abzhanov and Kaufman 1999).

Immunohistochemistry with monoclonal antibody 016C6 revealed that muscle mononucleate precursor cells that express myosin heavy chain can be labelled for the first time in stage 3 embryos of I. balthica and P. scaber (Fig. 4A,C). Sets of muscle precursors are arranged in a repetitive pattern within each podomere of the thoracic limbs and also the cephalic appendages, e.g. the second antennae (Fig. 4C,D). During subsequent development, these precursors enlarge to form a complex pattern of muscle precursors in the thoracopods (Figs. 4E, 5, 6 and 7).

Formation of a single identified muscle in the propodus of the thoracic limbs

Myogenesis will be exemplified by the formation of the identified, antagonistic muscles propodus 1 and $2(\operatorname{Pr} 1, \operatorname{Pr} 2$; Fig. 5), both of which are located in the propodus of the thoracic limbs and which move the dactylus in the adult 


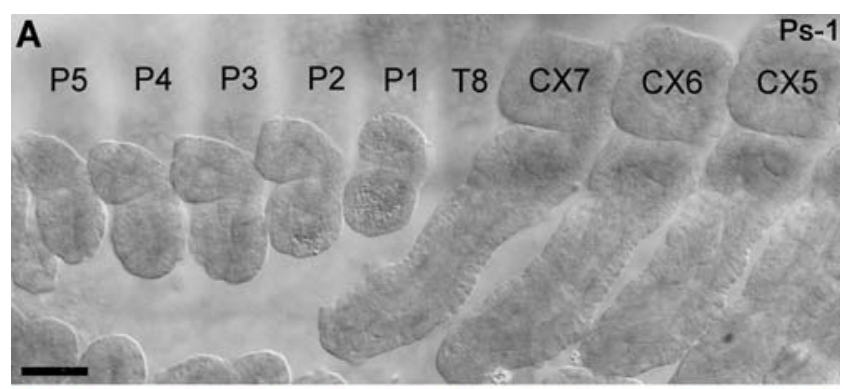

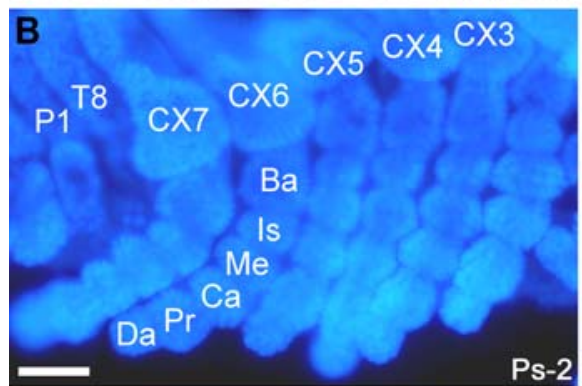
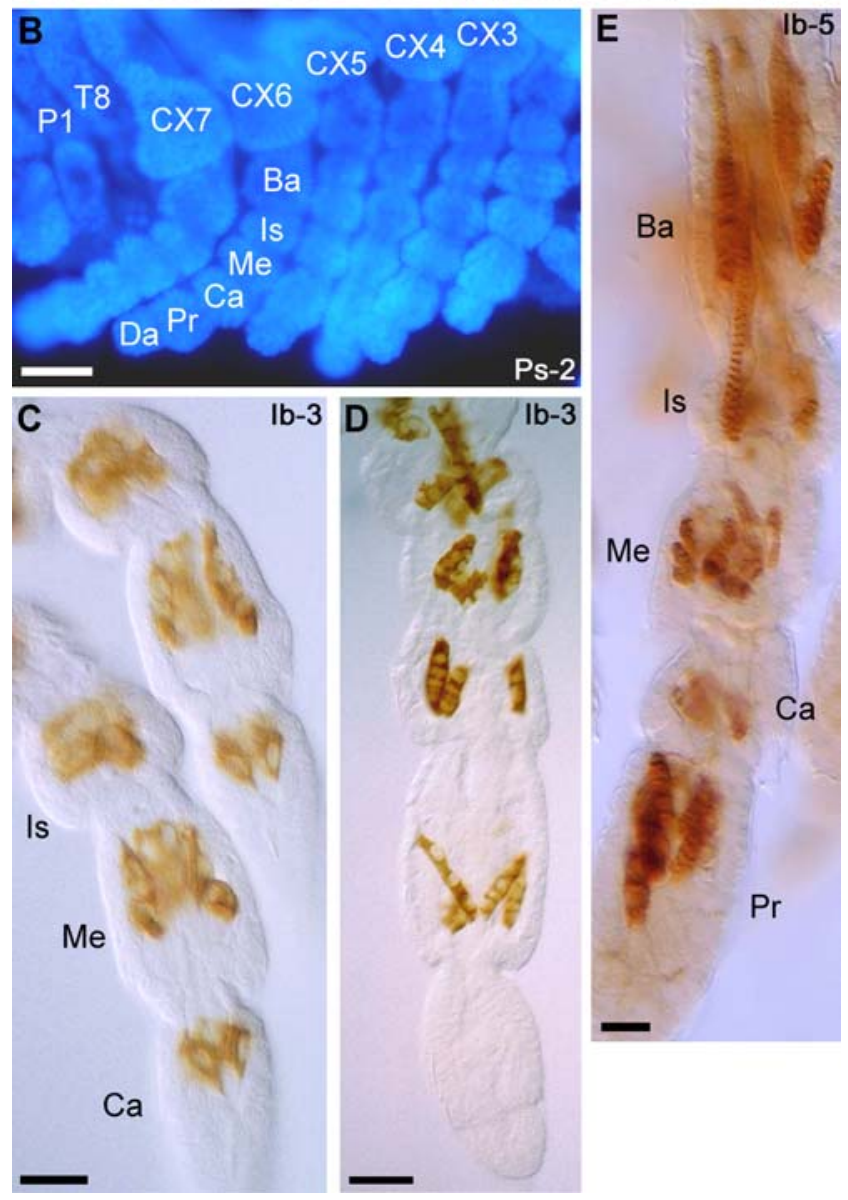

Fig. 4 Development of the walking limbs: A late stage 1 embryo $(P$. scaber), limb anlagen are present in the thoracic and pleonic segments except thoracomere 8; Normarsky interference contrast, ventral view, anterior is towards the right in all images of this figure. B stage 2 embryo ( $P$. scaber), the thoracic limbs are subdivided into characteristic podomeres, thoracopod 8 is still undeveloped, lateral view, HOECHST nuclear stain. $\mathbf{C}-\mathbf{E}$ Immunohistochemistry with monoclonal antibody 016C6 (I. balthica). Muscle precursor cells in thoracic limbs 5 and 6 (C), antenna 2 of stage 3 embryos (D) and matured muscle in thoracopod 5 of a stage 5 embryo (E). Abbreviations: letters in the upper right corners identify the species and larval stages; $\mathrm{Ba}$ basis, $C a$ carpus, $C X 2-7$ coxae of thoracopods 2 to 7, $D a$ dactylus, $I s$ ischium, $\mathrm{Me}$ merus, $\mathrm{P} 1-5$ pleomeres 1 to $5, \mathrm{Pr}$ propodus, $T 8$ thoracomere 8. Scale bars: A $30 \mu \mathrm{m}$, B $50 \mu \mathrm{m}, \mathbf{C}-\mathbf{E} 30 \mu \mathrm{m}$

(see below). Pr1 originates from single, mononucleate muscle precursors or muscle founder cells, which express myosin heavy chain both in stage 3 embryos of $P$. scaber (Fig. 5A,J; the mononucleate precursor cell of muscle Pr2 is
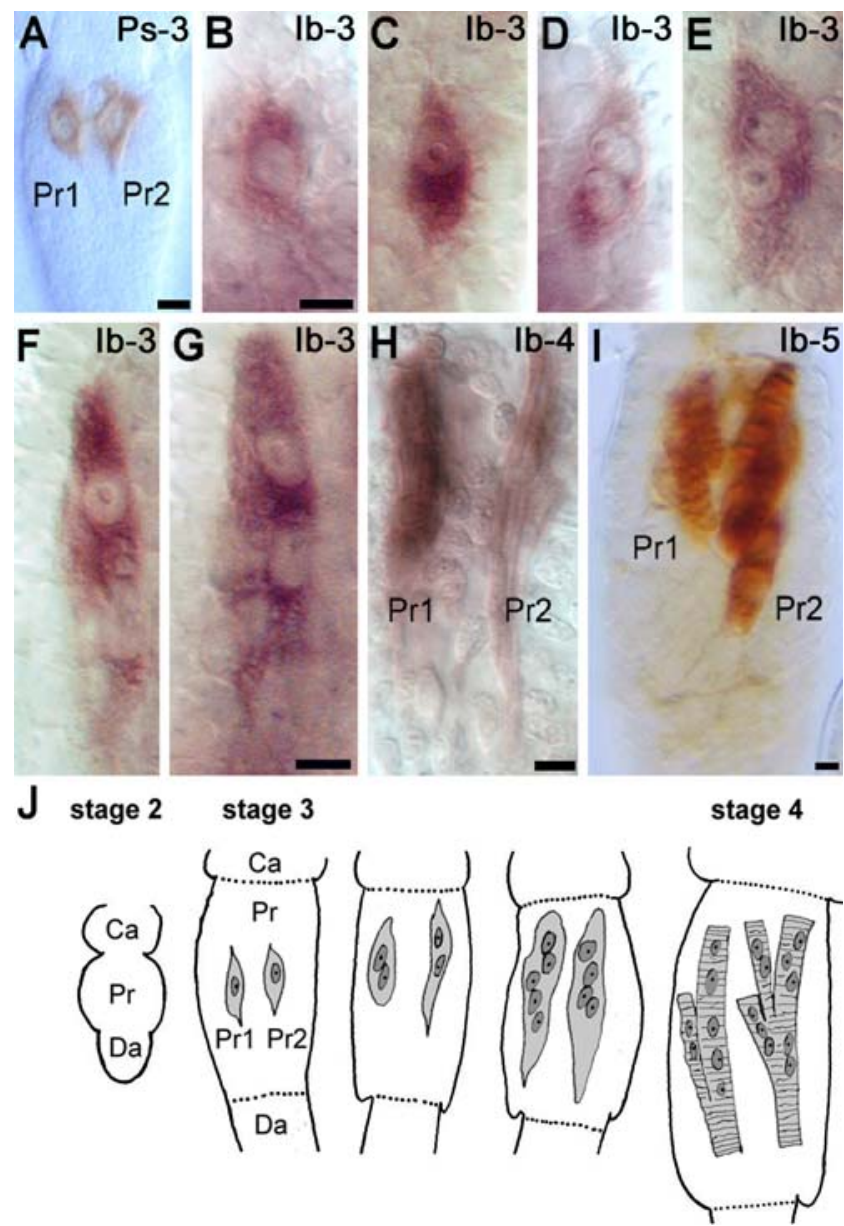

Fig. 5 Myogenesis in the limb anlagen: Immunohistochemistry with monoclonal antibody 016C6 in the propodus of the thoracic limbs. Muscles propodus one and two $(\operatorname{Pr} 1, \operatorname{Pr} 2)$ originated from single, mononucleate cells, the muscle precursors or muscle founder cells, both in stage 3 embryos of P. scaber (A) and I. balthica (B). During subsequent development, the precursor cell of Pr1 enlarged (C) and eventually developed into a binucleate, syncytial muscle precursor (D, I. balthica). This muscle precursor further enlarged in size (E) and became a multinucleate muscle precursor $(\mathbf{F}, \mathbf{G}$, I. balthica $)$. In stage 4 embryos, both muscles, Pr1 and the antagonistic Pr2, had developed into substantial primordial muscles $(\mathbf{H})$. In stage 5 embryos, before hatching, Pr1 and Pr2 had subdivided into two or three distinct subunits (I, I. balthica). J: Development of muscles Pr1 and Pr2 in the propodus of $I$. balthica, schematic representation. Abbreviations: letters in the upper right corners identify the species and larval stages; $C a$ carpus, $D a$ dactylus, $\operatorname{Pr}$ propodus. Scale bars: A-I $5 \mu \mathrm{m}$ (scale bar in $\mathbf{B}$ valid also for $\mathbf{C}-\mathbf{F}$ )

also shown) and I. balthica (Fig. 5B). During subsequent ontogeny, this mononucleate precursor cell enlarge (Fig. 5C) and eventually develop into a binucleate, syncytial muscle precursor (Fig. 5D,J). This muscle precursor further enlarges in size (Fig. 5E) and becomes a multinucleate muscle precursor (Fig. 5F,G,J). In stage 4 embryos, both muscles, Pr1 and the antagonistic Pr2, have developed into substantial primordial muscles (Fig. 5H). In stage 5 embryos, before hatching, Pr1 and Pr2 have subdivided into two or three distinct subunits (Fig. 5I,J). 


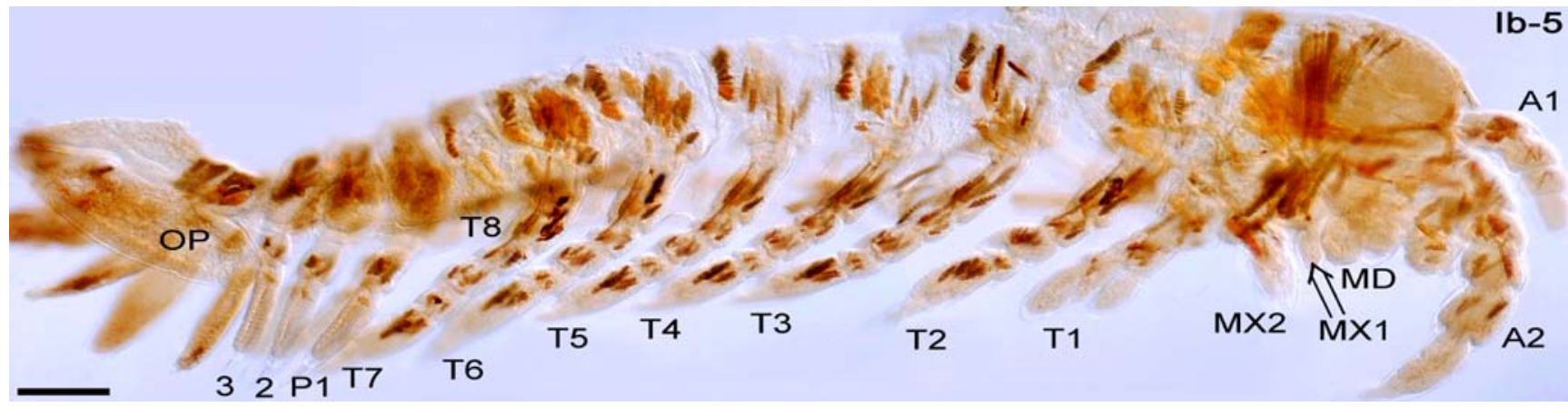

Fig. 6 Muscles in the whole mount of a pre-hatching embryo: Immunohistochemistry with monoclonal antibody 016C6, stage 5 (pre-hatching) embryo of I. balthica. Abbreviations: A1, 2 antenna 1 and 2, $M D$ mandible, $M X 1,2$ maxilla 1 and 2, $O P$ operculum, $P 1-3$ pleopods 1 to $4, T 1-7$ thoracic limbs 1 to 7 (T1 is a maxilliped), T8 thoracomere 8. Abbreviations: letters in the upper right corners identify the species and larval stages. Scale bar $100 \mu \mathrm{m}$
Muscle pattern in the thoracic limbs of pre-hatching embryos

Immunohistochemistry with 016C6 enabled us to map the primordial muscles in the thoracic appendages of I. balthica embryos before hatching (Figs. 6 and 7). As the adult pattern of muscles has not been mapped in the isopods which we examined, we labelled the primordial muscles with two letters to indicate the podomere in which they were located plus a number counting up the muscles from anterior to posterior (Fig. 7B). Me2, for example, designates muscle number 2 in the merus. Most embryonic muscles are arranged in antagonistic groups and are restricted to one podomere (Fig. 7B). Exceptions are $\mathrm{Ba} / \mathrm{Is} 1$ and $\mathrm{Ba} / \mathrm{Is} 2$, which span across the basis and the ischium (Fig. 7B). In the coxae, a complex system of muscles is present, which we failed to map.

To determine the function that the embryonic muscles will exert in the adult limbs, we examined the articulations and directions of movement of the successive podomeres in adult limbs of P. scaber (Fig. 1B,C) and I. balthica (Fig. 1A). These functions can be tentatively summarised as follows (Fig. 7B,C, Table 1): Ba7 serves as abductor of the ischium while $\mathrm{Ba} 1,2,3$ and $\mathrm{Ba} 4,5$ serve as adductors of the ischium that swings in a medial to lateral plane. The merus also moves in a medial to lateral plane and is abducted by Is 1 and $\mathrm{Ba} / \mathrm{Is} 1$ and adducted by $\mathrm{Ba} / \mathrm{Is} 2$ and Is 2, 3. The carpus swings in an anterior to posterior plane perpendicular to the merus. It is retracted by $\mathrm{Me} 2$ and protracted by Me1. The carpus also seems to have a limited freedom of movement in the medial to lateral. The propodus once more is displaced exclusively in a medial to lateral plane with $\mathrm{Ca} 3$ serving as the abductor and $\mathrm{Ca} 1$ and $\mathrm{Ca} 2$ as adductors. The dactylus swings in the same plane and is adducted by $\operatorname{Pr} 1$ and abducted by $\operatorname{Pr} 2$ and $\operatorname{Pr} 3$. The coax-basis joint was not examined in detail but seemed to allow displacement of the basis into several directions (Alexander 1972).
Development of muscles in the body wall

Although muscle precursor cells are not present in the anlagen of the thoracic limbs in late stage 1 embryos (Fig. 4A), there is already a distinct pattern of muscle precursors in the body wall [Electronic supplementary material (ESM) Fig. 1]. A bilateral band of ventral longitudinal (VL) muscle precursors is arranged parallel to the midline (ESM Fig. 1A). This band displays an anteriorposterior of maturation so that several steps of muscle formation can be observed in a single specimen (ESM Fig. 1B,C). As in the limbs, the ventral longitudinal muscles also originate from single muscle mononucleate precursor cells (inset ESM Fig. 1A), which span the length of one segment. These precursors subsequently develop into bi- (ESM Fig. 1B) and multinucleated muscle precursors (ESM Fig. 1C). In late stage 1 embryos, a band of dorsal longitudinal (DL) muscles is arranged in parallel to the ventral longitudinal muscles (ESM Fig. 1D,E). The ventral and dorsal bands of muscles are connected by single, segmentally iterated transverse muscle precursor cells (arrows in ESM Fig. 1E). In later stages, 016C6 also labelled a dense network of muscles surrounding the hindgut (ESM Fig. 1F).

During subsequent ontogeny, the muscle precursors of the longitudinal muscles mature into a more complex system of dorsal (extensors, ESM Fig. 2A) and ventral (flexors, ESM Fig. 2C) body wall musculature. A comparison of muscles in the leg-bearing thoracic segment and the leg-less eighth thoracomere enabled us to distinguish between muscles of the body wall and those that are associated with the coxa (Fig. 6, ESM Fig. 2B). In addition to the ventral and dorsal longitudinal muscles, distinct intersegmental extensor muscles are present in the eighth and the more anterior thoracomeres. These muscles transverse the border between two successive thoracomeres (Fig. 6, ESM Fig. 2A,B). Furthermore, two smaller 
Fig. 7 Map of muscle precursor in a walking limb: A Immunohistochemistry with monoclonal antibody 016C6, thoracic limb 5 , stage 5 (pre-hatching) embryo of I. balthica, frontal view, medial is towards the left. B Schematic drawing of the muscles in thoracic limb 5 of a stage 5 (pre-hatching) embryo of I. balthica (frontal view as in

A). Anteriorly arranged muscles are drawn in light grey, posteriorly arranged muscles are drawn in dark gray. The color scheme of the podomeres is according to Walossek (1999) and Waloszek (2003); see also Wolf and Harzsch (2002): coxa-red, basis-yellow, endopoditegreen. C Schematic representations of the directions of movement of the joints between the podomeres. Abbreviations: letters in the upper right corners identify the species and larval stages; $\mathrm{Ba}$ basis, $\mathrm{Ca}$ carpus, $\mathrm{Da}$ dactylus, Is ischium, Me merus, $\operatorname{Pr}$ propodus; for the terminology to label the muscles see text. Scale bar $25 \mu \mathrm{m}$

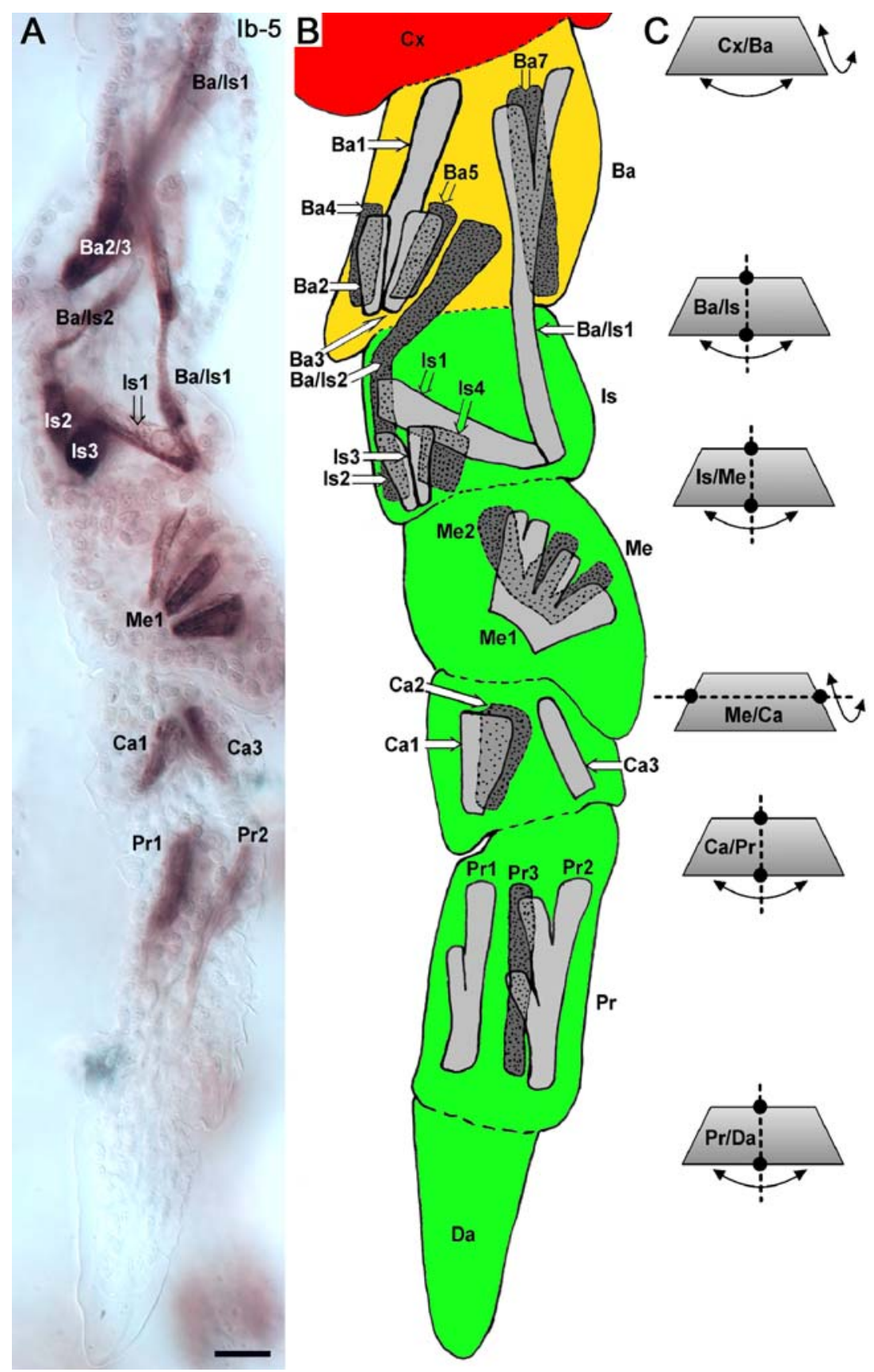

transverse muscles are found in each thoracomere (ESM Fig. 2B).

\section{Discussion}

\section{Myogenesis in Crustacea}

In recent years, cell lineages analyses in malacostracan embryos have set out to explore the earliest stages of mesoderm formation (Gerberding et al. 2002; Hertzler 2002, 2005), and the molecular mechanisms that underlie mesoderm formation have been explored in the emerging Crustacean model system, the amphipod Parhyale hawaiensis (Price and Patel 2008). Furthermore, in decapod Crustaceans, considerable effort has been directed towards understanding aspects of the ontogeny of the neuromuscular system such as outgrowth of motoraxons, development of the innervation patterns of muscles and synapse formation. These processes have been examined, e.g. in the body wall of the pleon (Cole and Lang 1980; Stephens and Govind 1981; Govind et al. 1985), the pleopods (Davis and Davis 1973; Kirk and Govind 1992) and the thoracic limbs (Costello et al. 1981; Govind and Pearce 1981, 1982, 1989; Govind et al. 1982; 
Govind and Derosa 1983; Pearce et al. 1985; Lnenicka et al. 1991; Arcaro and Lnenicka 1995). Myogenesis has been studied in the pleon of embryonic American lobsters on the electron-microscopic level (review Govind 1982, 1995). According to these accounts, the first signs of muscle formation are the appearance of small localised patches of myofilaments in multinucleated structures, the presumptive myotubes. Surrounding undifferentiated cells have enlarged nuclei with diffuse chromatin, Golgi apparatus, ribosomes and mitochondria and seem to resemble premyoblast cells (Govind 1982, 1995). The myofilaments then become organised in longitudinal arrays, and later, distinct sarcomeres with $\mathrm{A}, \mathrm{Z}$ and $\mathrm{I}$ bands appear. The muscle fibres grow in length either by the elongation of individual sarcomeres or the serial addition of sarcomeres (Govind 1982, 1995). Muscle development has also been studied in the embryos and nauplii of the dendrobranchiate shrimp Sicyonia ingentis using fluorescent phallotoxins to label F-actin (Kiernan and Hertzler 2006). In these animals, phalloidin labelling identifies muscle precursor that in the beginning are not striated and during mid-embryogenesis stretch along the entire length of the naupliar appendages (antenna one, antenna two and mandible). In this study, the analysis of myogenesis was restricted to these naupliar appendages and was followed up to the nauplius $\mathrm{V}$ stage when trunk appendages are still not developed (Kiernan and Hertzler
2006). Contrary to the dendrobranchiate $S$. ingentis which develops via nauplius larvae, the isopod species studied in the present study are direct developers so that a meaningful comparison of myogenesis in the trunk limbs is as yet not possible.

However, we can compare myogenesis in the pair of second antennae of this dendrobranchiate shrimp to the Isopoda. One major difference is that in Dendrobranchiata, the muscle precursors in antenna 2 span across the entire length of these appendages (Kiernan and Hertzler 2006), whereas in Isopoda, sets of individual muscle precursors are arranged in an iterated pattern within each podomere of the second antennae. Studies on appendage development in embryos of the American lobster Homarus americanus (Malacostraca, Homarida) using monoclonal antibody 016C6 (Harzsch and Kreissl, unpublished data) revealed that the pattern of myogenesis in this organism is different from that in Isopoda but rather resembles that in Dendrobranchiata. In lobster embryos, syncytial muscle precursor cells establish the muscles in the endopodites of the thoracic appendages and also in the second antennae. As in Dendrobranchiata, these muscle precursors initially stretch along the entire length of the appendages. During subsequent embryogenesis, the muscle precursors subdivide into several distinct units, thereby giving rise to iterated pairs of antagonistic primordial muscles in each of the

Table 1 Muscles in the walking limbs of crayfish and other Decapoda (Evoy and Ayers 1982; Atwood and Govind 1982; "common" names are also indicated), Isopoda (present report and Alexander 1972), Amphipoda (Brusca 1981)

\begin{tabular}{|c|c|c|c|}
\hline Muscles located in this podomere & Crayfish and other Decapoda & Idotea (Isopoda) & Cystisoma (Amphipoda) \\
\hline Thorax & Not shown & Not shown & Not shown \\
\hline \multirow[t]{3}{*}{ Coxa } & 2 Depressors of basis & 2 Extensor of basis & 2 Retractors of basis \\
\hline & 2 Levators of basis & 2 Flexors of basis & 2 Protractors of basis \\
\hline & & & $\begin{array}{l}2 \text { Rotators of basis } \\
\text { adductor of basis }\end{array}$ \\
\hline \multirow[t]{3}{*}{ Basis } & & Flexor of ischium & 2 Flexors of ischium \\
\hline & $\begin{array}{l}\text { Basis and ischium are fused in } \\
\text { adult Decapoda and contain the } \\
\text { reductor of merus }\end{array}$ & 3 Lateral extensors of ischium & 2 Extensors of ischium \\
\hline & & 2 Lateral extensors of ischium & \\
\hline \multirow[t]{3}{*}{ Ischium } & & 2 Flexors of merus & Flexor of merus \\
\hline & & 2 Lateral extensors of merus & 2 Extensors of merus \\
\hline & & 2 medial extensors of merus & \\
\hline \multirow[t]{3}{*}{ Merus } & Abductor of carpus (extensor) & Abductor of carpus & 3 Abductors of carpus \\
\hline & Adductor of carpus (flexor) & Adductor of carpus & 2 Adductors of carpus \\
\hline & Accessory adductor of carpus & & \\
\hline \multirow[t]{3}{*}{ Carpus } & Reductor of propodus (stretcher) & Flexor of propodus & 2 Flexors of propodus \\
\hline & Productor of propodus (bender) & Lateral extensor of propodus & 2 Extensors of propodus \\
\hline & Adductor of propodus (rotator) & Medial extensor of propodus & \\
\hline \multirow[t]{2}{*}{ Propodus } & Abductor of dactylus (opener) & Flexor of dactylus & 3 Flexors of dactylus \\
\hline & Adductor of dactylus (closer) & $\begin{array}{l}\text { Lateral extensor of dactylus } \\
\text { medial extensor of dactylus }\end{array}$ & 1 Extensor of dactylus \\
\hline Dactylus & No muscles & No muscles & No muscles \\
\hline
\end{tabular}

Muscles located within the thorax are not shown. 
successive podomeres (Harzsch and Kreissl, unpublished data), a layout which more and more resembles the arrangement in the adult thoracopods (see below and Table 1). We would predict that also in Dendrobranchiata, such an ontogenetic subdivision of the muscle precursors into individual iterated muscle primordia may take place, a question that should be explored by analysing later larval stages than have been studied so far. Considering that Kiernan and Hertzler (2006) reported striking similarities between the pattern of myogenesis between the dendrobranchiate $S$. ingentis and the brine shrimp Artemia salina (Crustacea, Branchiopoda) and considering that myogenesis in the American lobster H. americanus matches the SicyonialArtemia pattern (Harzsch and Kreissl, unpublished data), we conclude that these organisms most likely represent the ancestral Crustacean mode of myogenesis and that the slightly different mode that we observed in the present study for the Isopoda is derived from this ancestral pattern.

\section{Comparison of myogenesis in Crustacea and Insecta}

In the developing body wall of grasshopper embryos, Ho et al. (1983) were the first to describe large mononucleate mesoderm cells that arise early in development to erect a scaffold for later developing muscles, and they termed these cells muscle pioneers. The development of muscle pioneers in the body wall subsequently was also examined with antibodies different from that which Ho et al. (1983) used (Xie et al. 1992, 1994; Steffens et al. 1995). Furthermore, the role of muscle pioneers was extensively studied in the developing limbs of the grasshopper (Ball and Goodman 1985a, b; Ball et al. 1985) and a moth (Consoulas and Levine 1997; Consoulas et al. 1997). Since the discovery of muscle pioneers in the grasshopper, detailed analyses of myogenesis in the fruit fly has led to the establishment of the founder cell model for muscle patterning (reviewed in Campos-Ortega and Hartenstein 1997; Abmayr and Keller 1998; Baylies et al. 1998; Paululat et al. 1999a, b; Roy and VijayRaghavan 1999). According to this model, mesodermal progenitor cells in insects undergo mitosis to produce mononucleate muscle pioneers (termed founder cells in the fruit fly). These pioneers then differentiate into bi-, tri- or multinucleate syncytial muscle precursors by fusion with surrounding undifferentiated myoblasts.

Our present report applying a monoclonal antibody against myosin heavy chain extends the ultrastructural findings of Govind $(1982,1995)$ on muscle formation in malacostracan Crustaceans and suggests that in Isopoda, similar mechanisms of myogenesis as in insects may be present. This antibody labelled mononucleate myosinexpressing cells with morphological characteristics of insect muscle pioneers. Despite the differences between myo- genesis in isopods and the American lobster noted above, the latter organisms nevertheless also seem to employ mononucleate myosin-expressing cells to found their limb muscles (Harzsch and Kreissl, unpublished data). Similar to insects, the muscle precursors in the limb anlagen of the isopod Crustaceans we examined were individually identifiable and established the primordial adult muscle pattern. Furthermore, these cells developed into bi- and multinucleate syncyctia similar to insect muscle precursors. However, our methods did not enable us to determine whether this process is achieved via fusion with surrounding myoblasts as it is in insects. We conclude that in the moment, our knowledge on Crustacean myogenesis is too limited and too few species studied as to suggest a homology of the mononucleate Crustacean muscle precursors and insect muscle pioneer cells. Although the musculature in the limbs of non-malacostracan Crustaceans has been examined in depth, e.g. in Copepoda (Boxshall 1985, 1990, 1997), Cephalocarida (Hessler 1964), Branchiopoda (Benesch 1969; Fryers 1988) and Cirripedia (Wallay 1969), myogenesis has only been studied in two representative of the Branchiopoda (Williams and Müller 1996; Kiernan and Hertzler 2006) and a cirripede (Semmler et al. 2006). However, these studies were not conducted at the cellular level that would allow for a meaningful comparison with our data. Therefore, it remains unclear at this point whether mononucleate muscle precursor cells are part of the Crustacean ground pattern. Similarly, as the mechanisms of muscle formation are not known in any representatives of the Chilopoda and Progoneata (Myriapoda), we cannot answer the question whether mononucleate muscle pioneers are a class of muscle founder cells that represent a synapomorphy of Hexapoda and Malacostraca or if they were already present in the ground pattern of Euarthropoda.

Muscle arrangement in the adult limbs of Isopoda and Decapoda

The structural organisation of the neuromuscular system in adult Crustacean limbs is particularly well understood in Decapoda (reviewed in Wiersma 1961; Evoy and Ayers 1982; Govind and Atwood 1982; Rathmayer and Maier 1986; Wiens 1989; Rathmayer 1990, 2002; Cattaert and Le Ray 2001; Clarac 2002). In this taxon, muscles in the limbs exert their force on a system of levers formed by apodemes and joints, most of which operate in a single plane. Usually, the movements of an individual joint are brought about by a pair of antagonistic muscles located in the podomere proximal to the podomere which they displace. Successive joints along a particular appendage operate at an angle of approximately $90^{\circ}$ to one another, and most movements result from combinations of displacements at several joints. Three main joints are involved in locomotion: the thoraco- 
coxopodite joint allows forward and backward movements of the leg; the coxo-basipodite joint is responsible for upward and downward movements; the mero-carpopodite joint is responsible for extension and flexion of the leg (reviewed in Wiersma 1961; Evoy and Ayers 1982; Govind and Atwood 1982; Cattaert and Le Ray 2001; Clarac 2002).

In adult Isopoda, muscles have been extensively mapped in the cephalic appendages (Schmalfuss 1974) and the pleopods (Erhard 1997), but little information is available about the musculature of the thoracic limbs in the isopod taxa Oniscoidea and Valvifera. Von Haffner (1937) and Gruner (1954) described the morphology of the limbs in several isopod taxa but failed to individually identify the muscles, while Alexander (1972) only described the muscles located in the coxa. However, the limb musculature was mapped in several species of the amphipod genus Cystisoma Guérin-Méneville, 1842 (Hyperiidea; Brusca 1981). Table 1 summarises the muscle arrangement in adult Decapoda (Eucarida) and compares it with Amphipoda (Peracarida; Brusca 1981) and the isopod pre-hatching embryos (Peracarida) we studied. In all three species, the principle of paired antagonistic muscles (or muscle groups) is realised. However, while in Decapoda, in most cases, pairs of single antagonistic muscles are present, pairs of functional groups composed of two to five distinct muscles are found in Peracarida (von Haffner 1937; Brusca 1981). Furthermore, all successive joints in Decapoda operate at an angle of approximately $90^{\circ}$ (Evoy and Ayers 1982), while in Peracarida, only the planes of the merus-carpus joint and the carpus-propodus joint are twisted against each other (Fig. 7; and von Haffner 1937; Brusca 1981). Another difference is that in adult Decapoda, basis and ischium are fused and bear only one muscle, the reductor of the merus. These two podomeres are unfused in Peracarida and therefore contain sets of flexors and extensors (Table 1; and von Haffner 1937; Brusca 1981).

Acknowledgements D. Waloszek, H. Wolf and U. Rose, Ulm, Germany are gratefully acknowledged for improving the manuscript. We wish to thank H. Schmalfuss, Stuttgart, Germany for discussion and Matthias Thimm, Basel, Switzerland for rearing the marine Crustaceans and providing the image of the adult Idotea male. We also wish to acknowledge valuable support of $\mathrm{W}$. Rathmayer during initial stages of this work. This study was supported by Deutsche Forschungsgemeinschaft SFB 156 B5, Deutsche Forschungsgemeinschaft Grant Ha 2540/2 and University of Bielefeld FIF grant 20942.23. S. H. was a Heisenbergfellow of the DFG during the experimental part of this study.

Open Access This article is distributed under the terms of the Creative Commons Attribution Noncommercial License which permits any noncommercial use, distribution, and reproduction in any medium, provided the original author(s) and source are credited.

\section{References}

Abmayr SM, Keller CA (1998) Drosophila myogenesis and insights into the role of nautilus. Curr Topics Dev Biol 38:35-80

Abzhanov A, Kaufman TC (1999) Novel regulation of the homeotic gene $\mathrm{Scr}$ associated with a crustacean leg-to-maxilliped appendage transformation. Development 126:1121-1128

Abzhanov A, Kaufmann TC (2000) Homologs of Drosophila appendage genes in the patterning of arthropod limbs. Dev Biol 227:673-689

Aigner S, Gohlsch B, Hamalainen N, Staron RS, Uber A, Wehrle U, Pette D (1993) Fast myosin heavy chain diversity in skeletal muscles of the rabbit: heavy chain IId, not IIb predominates. Eur J Biochem 211:367-372

Akam M (1998a) The yin and yan of evo/devo. Cell 92:153-155

Akam M (1998b) Hox genes in arthropod development and evolution. Biol Bull 195:373-374

Alexander CG (1972) Locomotion in the isopod crustacean Ligia oceanica (Linn.). Comp Biochem Physiol 42A:1039-1047

Arcaro KF, Lnenicka GA (1995) Intrinsic differences in axonal growth from crayfish fast and slow motoneurons. Dev Biol 168:272-283

Averof M, Akam M (1995) Insect-crustacean relationships: insights from comparative developmental and molecular studies. Philos Trans R Soc Lond B 347:293-303

Averof M, Dawes R, Ferrier D (1996) Diversification of arthropod /Hox/ genes as a paradigm for the evolution of gene functions. Semin Cell Dev Biol 7:539-551

Averof M, Cohen SM (1997) Evolutionary origin of insect wings from ancestral gills. Nature 385:627-630

Averof M, Patel NH (1997) Crustacean appendage evolution associated with changes in Hox gene expression. Nature 388:682-686

Ball EE, Goodman CS (1985a) Muscle development in the grasshopper embryo II. Syncytial origin of the extensor tibiae muscle pioneers. Dev Biol 111:399-416

Ball EE, Goodman CS (1985b) Muscle development in the grasshopper embryo III. Sequential origin of the flexor tibiae muscle pioneers. Dev Biol 111:417-424

Ball EE, Ho RK, Goodman CS (1985) Muscle development in the grasshopper embryo I. Muscles, nerves, and apodemes in the metathoracic leg. Dev Biol 111:383-398

Baylies MK, Bate M, Gomez MR (1998) Myogenesis: a view from Drosophila. Cell 93:921-927

Benesch R (1969) Zur Ontogenie und Morphologie von Artemia salina. Zool Jb Anat 86:307-458

Bitsch J (2001) The hexapod appendage: basic structure, development and origin. In: Deuve $\mathrm{T}$ (ed) Origin of the hexapoda. Ann Soc Entomol Fr (NS) 37:175-194

Boxshall GA (1985) The comparative anatomy of two copepods, a predatory calanoid and a particle-feeding mormoniloid. Philos Trans R Soc Lond B 311:303-377

Boxshall GA (1990) The skeletomusculature of siphonostomatoid copepods, with an analysis of adaptive radiation in structure of the oral cone. Philos Trans R Soc Lond B 328:167-212

Boxshall G (1997) Comparative limb morphology in major crustacean groups: the coxa-basis joint in postmandibular limbs. In: Fortey RA, Thomas RH (eds) Arthropod relationships. Chapman and Hall, London, pp 155-168

Brena C, Liu PZ, Minelli A, Kaufman TC (2005) Abd-B expression in Porcellio scaber Latreille, 1804 (Isopoda: Crustacea): conserved pattern versus novel roles in development and evolution. Evol Dev 7:42-50

Browne WE, Patel NH (2000) Molecular genetics of crustacean feeding appendage development and diversification. Semin Cell Dev Biol 11:427-436 
Brusca GJ (1981) On the anatomy of Cystisoma (Amphipoda: Hyperiidea). J Crust Biol 1:358-375

Campos-Ortega JA, Hartenstein V (1997) The embryonic development of Drosophila melanogaster. Springer-Verlag, Berlin Heidelberg New York, p 405

Cattaert D, Le Ray D (2001) Adaptive motor control in crayfish. Prog Neurobiol 63:99-240

Clarac F (2002) Neurobiology of crustacean walking: from past to future. In: Wiese K (ed) Crustacean experimental systems in neurobiology. Springer-Verlag, Berlin Heidelberg New York, pp 119-140

Cole JC, Lang F (1980) Spontaneous and evoked postsynaptic potentials in an embryonic neuromuscular system of the lobster, Homarus americanus. J Neurobiol 11:459-470

Consoulas C, Levine RB (1997) Accumulation and proliferation of adult leg muscle precursors in Manduca are dependent on innervation. J Neurobiol 1997:531-553

Consoulas C, Anezaki M, Levine RB (1997) Development of adult thoracic leg muscles during metamorphosis of the hawk moth Manduca sexta. Cell Tissue Res 287:393-412

Costello WJ, Hill R, Lang F (1981) Innervation patterns of fast and slow motor neurones during development of a lobster neuromuscular system. J Exp Biol 91:271-284

D'Albis A, Pantaloni C, Bechet J (1979) An electrophoretic study of native myosin isoenzymes and of their subunit content. Eur $\mathrm{J}$ Biochem 156:291-296

Davis WJ, Davis KB (1973) Ontogeny of a simple locomotor system: role of the periphery in the development of central nervous circuitry. Am Zool 13:400-425

El Haj AJ (1999) Regulation of muscle growth and sarcomeric protein gene expression over the intermolt cycle. Amer Zool 39:570-579

Erhard F (1997) The pleonal skeleton and musculature of Titanethes albus (Synocheta) and of further taxa of the Oniscidea (Isopoda), with conclusion on the phylogeny of terrestrial isopods. Stuttgarter Beitr Naturk A 550:1-70

Evoy WH, Ayers J (1982) Locomotion and control of limb movements. In: Sandeman DC, Atwood HL (eds) The biology of Crustacea 4: neural integration and behavior. Academic, New York, pp 62-106

Fryers G (1988) Studies on the functional morphology and biology of the Notostraca (Crustacea: Branchiopoda). Philos Trans R Soc Lond B 321:27-124

Gerberding M, Browne WE, Patel NH (2002) Cell lineage analysis of the amphipod crustacean Parhyale hawaiensis reveals an early restriction of cell fates. Development 129:5789-5801

Gilbert SF, Opitz JM, Raff RA (1996) Resynthesizing evolutionary and developmental biology. Dev Biol 173:357-372

Gonzàles-Crespo, Morata G (1996) Genetic evidence for the subdivision of the arthropod limb into coxopodite and telopodite. Development 122:3921-3928

Govind CK (1982) Development of nerve, muscle, and synapse. In: Atwood HL, Sandeman DC (eds) The biology of Crustacea 3: neurobiology: structure and function. Academic, New York, pp 185-205

Govind CK (1995) Muscles and their innervation. In: Factor IR (ed) Biology of the lobster. Academic, New York, pp 291-312

Govind CK (2002) Synapse specification for regenerated motoneurons in crayfish muscle. In: Wiese $\mathrm{K}$ (ed) Crustacean experimental systems in neurobiology. Springer-Verlag, Berlin Heidelberg New York, pp 175-188

Govind CK, Atwood (1982) Organization of neuromuscular systems. In: Atwood HL, Sandeman DC (eds) The biology of Crustacea 3: neurobiology: structure and function. Academic, New York, pp 63-104

Govind CK, Derosa RA (1983) Fine structure of comparable synapses in a mature and larval lobster muscle. Tissue Cell 15: 97-106
Govind CK, Pearce J (1981) Remodeling of multiterminal innervation by nerve terminal sprouting in an identifiable lobster motoneuron. Science 212:1522-1524

Govind CK, Pearce J (1982) Proliferation and relocation of developing lobster neuromuscular synapses. Dev Biol 90:67-78

Govind CK, Pearce J (1989) Growth of inhibitory innervation in a lobster muscle. J Morphol 199:197-205

Govind CK, Walrond JP (1989) Structural plasticity at crustacean neuromuscular synapses. J Neurobiol 20:409-421

Govind CK, Meiss DE, Pearce J (1982) Differentiation of identifiable lobster neuromuscular synapses during development. J Neurocytol 11:235-247

Govind CK, Stephens PJ, Eisen JS (1985) Polyneuronal innervation of an adult and embryonic lobster muscle. J Embryol Exp Morph $87: 13-26$

Gruner HE (1954) Über das Coxalglied der Pereiopoden der Isopoden. Zool Anz 152:312-317

Harzsch S (2007) Architecture of the nervous system as a character for phylogenetic reconstructions: examples from the Arthropoda. Species, Phylogeny, Evolution 1:33-57

Harzsch S, Hafner G (2006) Evolution of eye development in arthropods: phylogenetic implications. Arthropod Struct Dev 35: 319-340

Hejnol A, Schnabel R, Scholtz G (2006) A 4D-microscopic analysis of the germ band in the isopod crustacean Porcellio scaber (Malacostraca, peracarida) - developmental and phylogenetic implications. Dev Genes Evol 216:755-767

Hertzler PL (2002) Development of the mesoderm in the dendrobrachiate shrimp Sycyonia ingentis. Arthropod Struct Dev 31:33-49

Hertzler PL (2005) Cleavage and gastrulation in the shrimp Penaeus (Litopenaeus) vannamei (Malacostraca, Decapoda, Dendrobranchiata. Arthropod Struct Dev 34:455-469

Hessler RD (1964) The Cephalocarida, comparative skeletomusculature. Mem Conn Acad Arts Sci 16:1-97

Ho RK, Ball EE, Goodman CS (1983) Muscle pioneers: large mesodermal cells that erect a scaffold for developing muscles and motoneurones in grasshopper embryos. Nature 301:66-69

Hughes CL, Kaufman TC (2000) A diverse approach to arthropod development. Evol Dev 2:6-8

Kiernan DA, Hertzler PL (2006) Muscle development in dendrobranchiate shrimp, with comparison with Artemia. Evol Dev 8:537-549

Kirk MD, Govind CK (1992) Early innervation of abdominal swimmeret muscles in developing lobsters. J Exp Zool 261: 298-309

Klass KD, Kristensen NP (2001) The ground plan and affinities of hexapods: recent progress and open problems. In: Deuve T (ed) Origin of the Hexapoda. Ann Soc Entomol Fr (NS) 37:265-581

Kreissl S, Weiss T, Djokaj S, Balezina O, Rathmayer W (1999) Allatostatin modulates skeletal muscle performance in crustaceans through pre- and postsynaptic effects. Eur J Neurosci 11:2519-2530

Kukalova-Peck J (1997) Arthropod phylogeny and "basal"morphological structures. In: Fortey RA, Thomas RH (eds) Arthropod relationships. Chapman and Hall, London, pp 249-268

Lnenicka GA, Hong SJ, Combatti M, LePage S (1991) Activitydependent development of synaptic varicosities at crayfish motor terminals. J Neurosci 11:1040-1048

Mellon De F Jr (1999) Muscle restructuring in crustaceans: myofiber death, transfiguration and rebirth. Am Zool 39:527-540

Mykles DL (1999) Proteolytic processes underlying molt-induced claw muscle atrophy in decapod crustaceans. Am Zool 39:541-551

Nulsen C, Nagy LM (1999) The role of wingless in the development of multibranched crustacean limbs. Dev Genes Evol 209:340-348

Panganiban G, Sebring A, Nagy L, Carroll S (1995) The development of crustacean limbs and the evolution of arthropods. Science 270:1363-1366 
Paululat A, Breuer S, Renkawitz-Pohl R (1999a) Determination and development of the larval muscle pattern in Drosophila melanogaster. Cell Tissue Res 296:151-160

Paululat A, Holz A, Renkawitz-Pohl R (1999b) Essential genes for myoblast fusion in Drosophila embryogenesis. Mech Dev 83:17-26

Pearce J, Govind CK, Meiss DE (1985) Growth-related features of lobster neuromuscular terminals. Dev Brain Res 21:215-228

Popadic A, Rusch D, Peterson M, Rogers BT, Kaufman TC (1996) Origin of the arthropod mandible. Nature 380:395

Popadic A, Panganiban G, Rusch D, Shear WA, Kaufman TC (1998) Molecular evidence for the gnathobasic derivation of arthropod mandibles and for the appendicular origin on the labrum and other structures. Dev Genes Evol 208:142-150

Price AL, Patel NH (2008) Investigating divergent mechanisms of mesoderm development in Arthropods: the expression of Ph-twist and Ph-mef in Parhyale hawaiensis. J Exp Zool Mol Dev Evol 308B:24-40

Rathmayer W, Maier L (1986) Muscle fiber types in crabs: studies on single identified muscle fibers. Amer Zool 27:1067-1077

Rathmayer W (1990) Inhibition through neurons of the common inhibitor type (CI-neurons) in crab muscles. In: Wiese K, Krenz WD, Tautz J, Reichert H, Mulloney B (eds) Frontiers in crustacean neurobiology. Birkhöäuser Verlag, Basel, pp 271-278, 7-190

Rathmayer W (2002) The study of neuromodulators-opening Pandora's box. In: Wiese K (ed) Crustacean experimental systems in neurobiology. Springer, Berlin, pp 165-168

Roy S, VijayRaghavan K (1999) Muscle pattern diversification in Drosophila: the story of imaginal myogenesis. BioEssays 21: 486-498

Schmalfuss H (1974) Skelett und Extremitäten-Muskulatur des Isopoden Cephalotorax: ein Beitrag zur Klärung von Phylogenie und Systematik der incertae-sedis-Familie Tylidae (Crustacea). Z Morph Tiere 78:1-91

Scholtz G, Mittman B, Gerberding M (1998) The pattern of Distal-less expression in the mouthparts of crustaceans, myriapods and insects: new evidence for a gnathobasic mandible and the common origin of Mandibulata. Int J Dev Biol 42:801-810

Schram FR, Koenemann S (2001) Developmental genetics and arthropod evolution: part I, on legs. Evol Dev 3:343-354

Semmler H, Høeg JT, Scholtz G, Wanninger A (2006) Preliminary results on the anatomy of the larval musculature of Balanus improvisus (Darwin, 1854) (Crustacea: Cirripedia: Thecostraca) using phalloidin staining in combination with confocal laser scanning microscopy. Invertebr Reprod Dev 49:207-212

Steffens G, Xie F, Kutsch W, Reichert H (1995) Segmental differentiation processes in embryonic muscle development of the grasshopper. Roux's Arch Dev Biol 204:453-464

Stephens PJ, Govind CK (1981) Peripheral innervation fields of single lobster motoneurons defined by synapse elimination during development. Brain Res 212:476-480

Strömberg JO (1965) On the embryology of the isopod Idotea. Arkiv för Zoologi 15:421-473

Ungerer P, Wolff C (2005) External morphology of limb development in the amphipod Orchestia cavimana (Crustacea, Malacostraca, Peracarida). Zoomorphology 124:89-99 von Haffner K (1937) Untersuchungen über die ursprüngliche und abgeleitete Stellung der Beine bei den Isopoden. Zeitschr wiss Zool (Leipzig) 149:513-536

Wallay J (1969) Studies on the larval structure and metamosphosis of Balanus balanoides (L.). Philos Trans R Soc Lond B 256:183-279

Walossek D (1999) On the Cambrian diversity of Crustacea. In: Schram FR, von Vaupel Klein JC (eds) Crustaceans and the biodiversity crisis. Proceedings of the Fourth International Crustacean Congress. Brill, Leiden, Boston, Cologne, pp 3-27

Waloszek D (2003) Cambrian "Orsten"-type preserved arthropods and the phylogeny of Crustacea. Legakis A, Sfenthourakis S, Polymeni R, Thessalou-Legaki M (eds) The new panorama of animal evolution. Proceedings of the 18th International Congress of Zoology, University of Athens, pp 69-87

Whitington PM, Leach D, Sandeman R (1993) Evolutionary change in neural development within the arthropods: axogenesis in the embryos of two crustaceans. Development 118:449-461

Wiens (1989) Common and specific inhibition in leg muscles of decapods: sharpened distinctions. J Neurobiol 20:458-469

Wiens TJ, Wolf H (1993) The inhibitory motoneurons of crayfish thoracic limbs: identification, structures, and homology with insect common inhibitors. J Comp Neurol 336:261-278

Wiersma CAG (1961) The neuromuscular system. In: Waterman TH (ed) The physiology of Crustacea II: sense organs, integration, and behavior. Academic, New York, pp 191-240

Williams TA (1998) Distalless expression in crustaceans and the patterning of branched limbs. Dev Genes Evol 207:427-434

Williams TA (2004) The evolution and development of crustacean limbs: an analysis of limb homologies. Crustac Issues 15:169-196

Williams TA (2008) Early Distal-less expression in the developing crustacean limb bud becomes restricted to setal forming cells. Evol Dev 10:114-120

Williams TA, Müller GB (1996) Limb development in a primitive crustacean, Triops longicaudatus: subdivision of the early limb bud gives rise to multibranched limbs. Dev Genes Evol 206:161-168

Williams TA, Nagy LM (1995) Brine shrimp add salt to the stew. Curr Biol 5:1330-1333

Williams TA, Nagy LM (1996) Comparative limb development in insects and crustaceans. Semin Cell Dev Biol 7:615-628

Williams TA, Nagy LM (2001) Developmental modularity and the evolutionary diversification of arthropod limbs. J Exp Zool (Mol Dev Evol) 291:241-257

Williams TA, Nulsen C, Nagy LM (2002) A complex role for distal-less in crustacean appendage development. Dev Biol 241:302-312

Wolf H, Harzsch S (2002) Evolution of the arthropod neuromuscular system: 1. Arrangement of muscles and excitatory innervation in the walking legs of the scorpion Vaejovis spinigerus (Wood, 1863) (Vaejovidae, Scorpiones, Arachnida). Arthropod Struct Dev 31:185-202

Xie F, Meier T, Reichert H (1992) Embryonic development of muscle patterns in the body wall of the grasshopper. Roux's Arch Dev Biol 201:301-311

Xie F, Garzino V, Therianos S, Meier T, Reichert H (1994) Embryonic expression of muscle-specific antigens in the grasshopper Schistocerca gregaria. Roux's Arch Dev Biol 204:141-145 